FOLIA PRAEHISTORICA POSNANIENSIA T. XXI - 2016

INSTYTUT ARCHEOLOGII, UAM POZNAŃ - ISSN 0239-8524

http://dx.doi.org/10.14746/fpp.2016.21.23

\title{
EMMANUEL ANATI (RED.), MEANING OF ABSTRACT SIGNS?, EXPRESSION 2016, NR 13
}

Recenzja „Meaning of abstract signs?”, międzynarodowego e-czasopisma poświęconego sztuce, archeologii, antropologii, a zwłaszcza poglądom po przełomie konceptualnym, opublikowanego w ramach tomu Expression (2016, nr 13). Tom ten stanowi zwartą, monotematyczną monografię. Czasopismo wydawane jest przez Emmanuela Anatiego, wybitnego znawcę sztuki pradziejowej i wczesnodziejowej, wieloletniego badacza sztuki w Vall Camonica i dyrektora tego muzeum. Jest to kwartalnik publikowany przez Atelier, a wydawany przez międzynarodową Commission on Intellectual and Spiritual Expressions of Non-Literate Peoples (UISPP-CISENP).

$\mathrm{Na}$ łamach tego tomu czasopisma dyskutowane są najnowsze zagadnienia dotyczące sztuki pradziejowej, jak i ogólnie społeczeństw prostych, niepiśmiennych. Tom stanowi również zapowiedź tematyczną kolejnego i zachęca do publikacji na dany temat.

Rozpoczyna go wprowadzenie pt. „Abstrakt for you not for me” (s. 2), wskazujące na antropologiczne przykłady konsekwencji braku znajomości miejscowych obyczajów, kultury, które prowadzą do nieprzyjaznych zachowań albo do niemożności zrozumienia innych ludzi, kultur. Przykład obrazu, na którym malarz zaprezentował klan podejmujący w istocie decyzję o wydaleniu intruza, który polował na ich terenie, ale bez ich zgody. Zaprezentował ich siedzących nad wodą ze strzałami i z tarczami. Dla Aborygenów tarcza jest narzędziem wojennym, a strzały stosuje się w życiu codziennym, dlatego tarcze nie powinny się znaleźć na tym obrazie. To, co było abstrakcyjne, bez znaczenia dla malarza Europejczyka, miało konkretne znaczenie dla ludności miejscowej, a z kolei złamanie konwencji przedstawiania przez tego malarza sprawiło, że obraz był „abstrakcją” dla miejscowej ludności. Obraz rozmijał się ze znaczeniem podejmowanych przez nich czynności. Równie dobrze może się to odnosić do sztuki pradziejowej.

Kolejna ważna idea propagowana w tym tomie to „Conceptual Anthropology” (s. 2-5), który to zamysł nauki/dziedziny wiedzy po przełomie konceptualnym ma łączyć różne aspekty nauk humanistycznych i społecznych w odniesieniu do zachowań ludzkich w kulturze, wykorzystując doświadczenia z przeszłości, aby zrozumieć teraźniejszość i budować przyszłość (s. 2). Idea tej nauki powstawała od jakiegoś czasu, natomiast została sformułowana w 2011 r. w Brazylii przez Komitet Naukowy Unii Nauk Pra- i Protohistorycznych i do dziś jest rozwijana. Celem tej dyscypliny jest zrozumienie ludzkich zachowań i tendencji kulturowych zarówno pojedynczych zjawisk, jak i procesów. Odnosi się ona do badań nad ludzkim umysłem, nad działaniami zakorzenionymi w pamięci historycznej, technicznej, ale też obecnej - elektronicznej. Można to ująć następująco, że włącza osiągnięcia współczesnej 
kognitywistyki do badań nad sztuką pradziejową, nad procesami poznawczymi ludzi z tak odległej przeszłości. Owa antropologia poznawcza stanowi próbę wyjścia z wąskich specjalizacji na rzecz podejmowania multidyscyplinarnych badań, dialogu między antropologami, archeologami, socjologami, psychologami, filozofami. Jej dążeniem jest wypracowanie pewnej wizji kulturowej, której nie da się sprowadzić do technicznych rozwiązań.

Ważny dział stanowi „Forum dyskusyjne” (s. 6), jako zapowiedź tematyki kolejnego tomu. Miał nim być problem „Kolonizacji” i zachęta do wypowiedzi na ten temat, ponieważ, jak się wydaje, człowiek skolonizował całość Ziemi, jednak każdy przypadek rozważany z innej perspektywy może dać interesujące rozwiązania. Badania różnych kontynentów, wysp wskazują na różne historie czy fale kolonizacji, od hominidów, przez człowieka, a następnie społeczności rolnicze itd.

Z mojej perspektywy bardzo interesującym artykułem jest ten, który dotyczy ognia i jego przedstawień (reprezentacji) w sztuce pradziejowej i społeczeństw plemiennych. Autorem jest E. Anati, który przedstawił swoją korespondencję ze specjalistami w zakresie sztuki pradziejowej, ich argumentację oraz własne przemyślenia na temat przedstawiania (bądź nie) ognia przez te społeczności. Dyskusja ta ma tytuł: „Fire. The question of fire: how is it represented in prehistoric and tribal art?" (s. 7-15) Anati zaczyna od stwierdzenia, że to małe pytanie wywołało wielką dyskusję. W swojej książce pt. Decoding Prehistoric art and the Origins of Writing zinterpretował ryty na fragmencie kości z Les Eyzies, datowane na paleolit górny, jako ideogram ognia. Bardzo sceptycznie na tę ideę zareagował w styczniu $2016 \mathrm{r}$. niemiecki badacz Dieter Redlich, porównując tę tezę do tego, jak thumaczyć historię migracji z Azerbejdżanu do dzisiejszej Francji. Anati uważa, że interpretujemy, czytamy sztukę pradziejową i że nadszedł czas, aby to czynić odważnie, aby szukać jej znaczenia, a nie tylko opisywać to, co się widzi. Uważa dalej, że gramatyka i składnia są w naszych strukturach poznawczych wcześniejsze niż konwencjonalne pismo, dlatego sztuka mogła być takim polem. Na kości, w części po jej prawej stronie, jest przedstawiony bizon z profilu, a pozostałą część kompozycji zajmuje 8 postaci antropomorficznych, trzymających na swoich barkach rozwidlone przedmioty - patyki. U góry sceny są dwa takie przedstawienia o wiele większe, a z boku, z lewej strony, niejako z tyłu idących postaci antropomorficznych - kolejne dwa, równie duże i mocno rozwidlone. Anati zinterpretował to jako przedstawienie dwóch światów: „świat/obszar bizona”, a z drugiej strony - „świat/obszar ognia”. Anati uważa, że w Kantabrii, podobnie jak w Azerbejdżanie, wydobywająca się ropa i gaz mogły tworzyć ogniowe choreografie, które w taki sposób były przedstawiane w rytach naskalnych. Anati wysłał to zapytanie do kilku badaczy sztuki na różnych kontynentach. Badacz sztuki australijskiej Benjamin Smith (s. 9) odpisał mu, że wyobrażenia ognia w sztuce Aborygenów są rzadkie, choć przesłał rysunek ludzi siedzących wokół ogniska z 1971 r., interpretując go w kategoriach rytualnych. Najwięcej przykładów, również zbliżonych formą do tego paleolitycznego, Anati znalazł w Indiach (Wzgórze Mahadeo, ryc. E. Neymayer), gdzie przedstawiono przenoszony w okrągłym przedmiocie/naczyniu ogień w rozwidlonej postaci czy w formie ,pierzastej”, w kontekście przygotowywania potraw przez kobiety. Podobny przykład przedstawienia ognia w postaci przedmiotu podwójnie rozwidlonego na grube, żółte, zygzakowate odnogi, trzymane w ręce przez postać antropomorficzną, pochodzą z Arizony w USA i dotyczą sztuki naskalnej ludności Pueblo (okres I i II tej sztuki). Z kolei przykład średniowiecznej sztuki naskalnej wikińskiej, reprezentującej zestaw narzędzi kowala, nie zawiera przedstawienia ognia, a interpretowany jest jako tekst mitologiczny (s. 12). 
Przyznam, że od dłuższego czasu zastanawiał mnie brak w literaturze przedmiotu dyskusji badaczy na temat przedstawień ognia w paleolitycznym malarstwie i rytach naskalnych. Oprócz opisanej przez Anatiego kości z Les Eyzies, taki sam znak-ryt „odkryłam” na skale w jaskini Trois Frères (nie odwołuje się do niego Anati) - w postaci mocno rozwidlonej. Dlatego uważam, że takie wyobrażenia występują w sztuce naskalnej - rzadko zauważane przez badaczy, też nieczęste, ale o określonej, konwencjonalnej formie pozwalającej na interpretację tych wyobrażeń jako reprezentacji ognia. Są to ryty, co potwierdzałoby kolejną „uniwersalną” właściwość ludzkiego umysłu do przedstawiania rzeczy niebezpiecznych i gwałtownych, „ostrych”, w postaci rytów, a nie malowideł. W sztuce paleolitu ogień mógł mieć jeszcze znaczenie mniej oswojonego; z czasem stawał się coraz bardziej przydatny, wręcz niezbędny i coraz szerzej stosowany. Teza, że początkowo sztuka mogła mieć charakter bardziej abstrakcyjny, sprawdza się w takim sensie, że ogień nie miał ustalonego kulturowego znaczenia, to i jego przedstawienia mają również bardziej abstrakcyjny charakter - są to znaki, które interpretujemy jako symbole ognia czy reprezentacje ognia.

Kolejny artykuł, autorstwa Margalit Berriet, nosi tytuł „Abstrakt signs and symbols in prehistoric to modern art” (s. 16-22). Autorka wychodzi z założenia, że przedstawienia w sztuce od paleolitu po nowoczesność obejmują trzy kategorie: ludzi, zwierzęta, znaki geometryczne, które staramy się interpretować naszymi zmysłami i rozumem. Stara się znaleźć uniwersalne zasady w przedstawianiu ludzkiej postaci lub ptaka (za pomocą dwóch patyków, często przecinających się i niejako przekraczających samych siebie). Autorka uważa, że każdy znak może być symbolem, który stanowi specyficzny sposób skodyfikowania świata kultury, w tym sztuki. Dlatego poznanie sztuki przybliża nas do poznania symbolicznego myślenia i w jego pluralizmie pozwala dostrzec podobne i powszechne komunikaty. W moim rozumieniu rozważania autorki stanowią echo strukturalizmu i tęsknoty za nim, jako docierającego do struktur głębokich. Przytacza liczne przykłady od paleolitu, przez najstarsze cywilizacje, w tym sumeryjską, jak postęp w komunikowaniu się i stosowanie coraz to bardziej skomplikowanych znaków, symboli sprzyjał tworzeniu praktycznego porządku logicznego, pozwalającego na ujęcie i panowanie nad cyklami życia. Współczesna neurologia wskazuje na ścisły związek między percepcją a twórczością. W 2009 r. Mark Changizi wykazał, że znaki alfabetyczne i ideogramatyczne ewoluowały z form naturalnych i że reakcja mózgu na te znaki jest taka sama, jak na prototyp w formie naturalnej. Tak więc forma znaków nie wynika jedynie z kultury, ale z ludzkiej zdolności rozpoznawania form naturalnych. Poglądy te idą tropem E. Cassirer'a (1923, s. 234), który ujmował język, mit i sztukę jako formy symboliczne, ale powstające w ramach intuicyjnych działań, kształtowanych przez ich funkcję. Pisanie, rysowanie jest tworzeniem konkretnych aluzji, a wraz z rozwojem staje się coraz bardziej abstrakcyjne. Autorka artykułu odwołuje się do egipskich hieroglifów, pokazując, jak między znakiem a jego pierwotną formą i kolejnymi zapożyczeniami toczy się gra semantyczna. Również przykłady sztuki współczesnej świadczą o łączeniu emocji z graficznym przedstawieniem na obrazie. Artykuł odwołuje się do sztuki tworzonej przez dzieci i do powtarzających się motywów - np. zygzaki, koła, operowanie kontrastem koloru i bardzo abstrakcyjnymi formami.

Kolejny tekst dotyczy tzw. Studni Martwego Człowieka w jaskini Lascaux (,The Lascaux shaft", s. 22-24), a jego autorem jest Jean Clottes. Problem jednoczasowego wykonania nosorożca i pozostałej części sceny: umierającego człowieka, rannego bizona i ptaka na pali- 
$\mathrm{ku}$ - jest raczej rozstrzygnięty negatywnie ze względu na różny pigment czarnej farby (tlenek manganu), zbliżony do wizerunku konia po przeciwnej ścianie jaskini. Clottes zauważa, że w tak głębokim miejscu w jaskini występowało bardzo wysokie stężenie dwutlenku węgla i mogło nastrajać do myślenia o śmierci i jej przedstawiania albo że scena odnosi się do transu szamańskiej podróży, lotu szamana. Odwołuje się do znanych przykładów, gdy w kulturach typu szamanistycznego śmierć stanowi metaforyczne odniesienie do transu szamana. Można dodać, że taka interpretacja zyskała na popularności w ostatnich latach, a przyczyniła się do tego również neurobiologia, ukazująca zmienione stany umysłu pod wpływem transu.

Autorem kolejnego artykułu „Text, context and symbolism in sacra art: An anthropological analysis" (s. 25-32) jest Jagannath Dash. Artykuł ukazuje plemię Saora, które żyje w ściśle określonej niszy ekologicznej, tworząc również sztukę. Plemię to szanuje zarówno przyrodę, jak i istoty nadprzyrodzone. W sztuce, w postaci ikonu lub malarstwa naściennego, odzwierciedla wszystkie swoje społeczno-kulturowe uczucia, nastroje, emocje. Przedstawiciele plemienia w pełni rozumieją, że bez przychylności i błogosławieństwa bogów i bogiń oraz składanych im ofiar z roślin i zwierząt ich byt na ziemi byłby niemożliwy. Z kolei symboliczne treści przedstawień i sztuki wpływają na myśli i uczucia każdego z nich. Przykład tego plemienia świadczy, że sztuka ma charakter symboliczny, jest silnym medium w ich społeczności, kształtującym wartości kulturowe. Sztuka w tym ujęciu kształtuje w efekcie społeczeństwo i ludzi, a nie odwrotnie.

Kolejny artykuł, autorstwa Maurera Dietera, to „In picture genesis, the abstract precedes and enables depiction and coding: some arguments and speculations of early pictures in ontogeny" (s. 33-41). Problem ontogenezy rysunków i obrazów prowadzi autora do tych, wykonywanych przez dzieci. Bierze pod uwagę tę twórczość z różnych geograficznie miejsc, różnorodnych społecznych kontekstów, a przedział wiekowy dzieci obejmuje wiek od 1 do 6 lat. Podkreśla, że takie badania były prowadzone wcześniej (m.in. przez Mauer, Riboni, Gujer). Uważa jednak, że sztuka paleolityczna nie może być ujmowana jako tworzona przez dzieci, ponieważ pojawia się w rozwiniętej postaci. Ponadto, co słusznie zauważa autor, tendencje rozwojowe w zakresie grafiki są inne u dorosłych niż u dzieci ze względu na zdolności poznawcze, sensomotoryczne i kompetencje kulturowe, co stanowi najważniejszą przyczynę, dla której nie można ich utożsamiać, a nawet porównywać. Dotyczy to każdej kultury i każdego czasu. Autor poszukuje genezy obrazów, przedstawień w rysunkach dzieci, jednak uważa, że przedstawienia nie pojawiły się kiedykolwiek w „czystej” postaci. Twierdzi, że są one wynikiem kulturowych zachowań, przeżyć i zasad, a także tradycji, sposobów uczenia się, komunikowania. Przejawy graficzne są silnie powiązane z życiem społecznym, kontekstem społecznym i interakcjami. Jednak pewna powtarzalność ściśle określonych znaków graficznych na początkowych etapach rozwoju sztuki może być tłumaczona jego zdaniem jako konsekwencja kontemplacyjnych stanów umysłu.

Przechodzimy do kolejnego artykułu - „Abstract signs in art as shorthand for cultural structure" autorstwa Edmunda Purtera (s. 42-53). Autor uważa, że niektóre abstrakcyjne formy w sztuce naskalnej są graficzne, ale często słabo czytelne. Część ich znaczeń znajduje ilustrację i wyraża się w micie, rytuale i okazjonalnych konwencjach. Łączy je z kulturą wizualną. Uważa również, jak wcześniej strukturaliści, że istnieją - przynajmniej częściowo - uniwersalne cechy kultury, że istnieje gramatyka kultury wizualnej, a więc i sztuki, której część zasad jest przyjmowana intuicyjnie. Podał przykład analizy 500 zabytków sztuki na- 
skalnej z Południowej Afryki, powtarzalności jej elementów i układów przestrzennych. Analogiczną strukturę odkrył w sztuce egipskiej i przedstawieniu boga Seta. Celem było wskazanie archetypu (pierwowzoru) symboliki astronomicznej, a następnie archetypicznej struktury hieroglifów, struktury abstrakcyjnych liter czy symboli abstrakcyjnych. Abstrakcyjne kształty są przedstawieniami ekspresji strukturalnej, ponieważ jest to sztuka figuratywna. Uważa, że występuje archetyp struktury w sztuce naskalnej. Autor nie jest zwolennikiem paradygmatu ewolucyjnego rozwoju sztuki. Jednak uważa, że istnieją w strukturze sztuki abstrakcyjnej znaki, jako psychogramy, które mają uniwersalny sens i wyrażają archetyp danej struktury jako pewnego przymusu, jako podświadomego wyrażania treści kulturowych. Wielu badaczy uważa, że istnieje logiczna akumulacja ról i doświadczeń życiowych i że ta zasada jest wrodzona i wieczna. Z kolei znaki abstrakcyjne nie mogą być oddzielone od kultury; są przywoływaniem nieobecnego; są wizualnym skrótem do kultury. Sztuka stanowi matrycę dla kultury, choć ją zniekształca, „opracowuje” na swój sposób, jest swoistym sitem kultury. Dlatego autor dochodzi do wniosku, że skoro egipskie hieroglify przez stulecia nie różniły się strukturą, to również w odniesieniu do sztuki powinien istnieć archetyp rozumiany jako podstawowa struktura, którą należy uwzględniać w definicji sztuki, piktogramu, znaku, ideogramu, psychogramu, hieroglifów, alfabetu, komunikacji, gramatyki, rytuału i kultury.

Kolejni autorzy, Tirtha Prasad Mukhopadhyay i Alan P. Garfinkel, napisali artykuł pt. „Patterned body anthropomorphs of the Cosos: How might concentric circle psychograms function in ethnographic schemes?" (s. 54-70). Artykuł poświęcony sztuce z Coso we wschodniej Kalifornii, niezwykle bogatej we wzory i układy przestrzenne. Autorzy zajęli się analogiami między zdobieniem ciał a sztuką naskalną, odkrytą w Kalifornii. Motywy te są nadal obecne w tradycji ustnej i w kulturze symbolicznej potomków Uto-Azteków, w tym ludów Hopi i Hichol. Uważają że te przedstawienia są swoistymi archetypami zachowywanymi w różnych wariantach do dziś. Powstało Amerykańskie Stowarzyszenie Badań nad Sztuką Naskalną (ARARA), badające procesy formalizacji i powstawania abstrakcyjnych wyobrażeń bóstw, szamanów, istot pozaziemskich, zwierząt i ich symbolicznych znaczeń w Mezoameryce. Powtarzające się wzorce w tej sztuce mogą stanowić uniwersalne „,szablony" przedstawiania np. oczu ludzkich, zwierzęcych, aby przejść do oka-boga w danych kulturach. Autorzy uważają, że te prefiguratywne motywy stanowiły uniwersalne elementy w ikonografii ludów Mezoameryki.

Z kolei Tsoni Tsonev napisał artykuł pt. „Conceptualizing the nature of abstract representations in prehistory" (s. 71-77). Autor uważa, że aby móc jednoznacznie odczytać znaki pochodzące z pradziejów, zwłaszcza z paleolitu, to musiałyby one reprezentować sztywne kategorie ówczesnej wiedzy, a to nie jest możliwe. Jednak analizy formy, występowania znaków, ich ładunku treściowego w przestrzeni ujawniają cechy ewolucji zdolności poznawczych człowieka przez budowanie zintegrowanego środowiska przyrodniczego i kulturowego. Autor zaleca stosowanie wielu metod weryfikacji naszych hipotez w kwestii znaków, wyobrażeń, form zygzakowatych, antropomorficznych itp. i nie przypisywania intencji twórcom, co do których nie mamy żadnych uzasadnień. Zajął się zdobieniami dwóch z tellu Gabarevo, Stara Zagora: jedno zdobione w różnorodne wzory geometryczne, a drugie, antropomorficzne, upozorowane na mężczyznę, pokazując, jak puste przestrzenie stawały się dogodnymi miejscami do kształtowania intersubiektywnych interakcji, a także budowania tożsamości indywidualnych i zbiorowych. Stylizacje ludzkiego ciała reprezentują złożony, 
dynamiczny proces, w którym role grają różne materiały i środki prowadzące do „odnotowywania" znaczenia społecznego, tożsamości społecznej. Kombinacje symboli budują tożsamości zbiorowe poprzez relacje interpersonalne.

Z kolei Leslie Van Gilder zajęła się problematyką „Finger flutings, tectiforms and the audacity of Hope" (s. 78-86). Uważa, że badamy malowidła w jaskiniach z nadzieją, że zawierały one cechy umysłowości tamtych ludzi, ale oni już nie mogą mówić sami za siebie. Wyszła od współczesnego przykładu ludności Pueblo w USA, gdzie jeden z przedstawicieli starszyzny wykonywał prace upamiętnienia w sztuce naskalnej ich aktualnej historii. Autorka artykułu miała możliwość obserwowania tych prac. Sam twórca wprowadzał dramaturgię i snuł opowieści o stworzeniu oceanów itp., a następnie zapytał o interpretację tego, co namalował, tych, którzy mu towarzyszyli. Wielu wyraziło swoje opinie, on tylko się uśmiechał i na koniec pokazał na panelu mały znak zrobiony paznokciem i powiedział, że to najważniejsza rzecz na tym panelu: „to pamięć o deszczu”. Na tej kanwie autorka pokazała rysunki i figury wykonane palcami (jako palcowe kanelury) w jaskiniach paleolitycznych. Występują one w całej sztuce w jaskiniach m.in. w El Castillo, w Gargas, Chauvet, Pech Merle i Altamirze, jak również w Las Chimenas czy w Rouffignac. Niektóre z nich układają się w formy zwierząt, np. bizony, nosorożce, mamuty, natomiast inne tworzą kształty szałasów, daszkowate czy mało czytelne wzory. Celem była identyfikacja ilości osób wykonujących te „rysunki” palcami. Zastosowano wypracowaną metodologię identyfikacji poszczególnych form tektonicznych. Część z tych przedstawień udało się przypisać dzieciom w wieku 4-5 lat. Uwzględniła m.in. Gargas, w której kilka paneli zostało wykonanych przez osobę leworęczną, przez wprowadzenie specyficznych linii - pozostali twórcy ich nie stosowali. Twórca ten musiałby być jednak wyjątkowo wysoki, dlatego autor artykułu zawarł sugestię, że być może te nietypowe linie wykonało dziecko znajdujące się na ramionach osoby dorosłej. Owe tektiformy (,daszkowate”) stanowią podstawę dążenia do poznania znaczenia tych linii i tego, kto je wykonał. Poszukuje się indywidualnych identyfikatorów poszczególnych artystów, którzy malowali jaskinie na różne sposoby, również palcami. Użycie danych palców może wskazywać na przemyślaną formę komunikacji. Jest w tym artykule tęsknota za tym, że istnieją jakieś markery znaczenia, pozwalające dostrzec indywidualne różnice między twórcami malowideł. Niekiedy się to nawet udaje i argumentacja jest przekonująca, a może tylko perswazyjna? Kwestia, co artysta przekazywał, czy myśli i idee, czy może uczucia i doznania - zmienia zupełnie perspektywę badań w zakresie interpretacji.

Tom zawiera też krótkie omówienie nowych monografii, głównie o sztuce pradziejowej i starożytnej.

Każdy z artykułów, czy się z nim zgadzamy, czy nie, zawiera pewien pomysł na poszukiwanie zasad, które byłyby kluczem do interpretacji sztuki pradziejowej i antycznej. Ich treść podparta jest nowymi osiągnięciami w zakresie nauk społecznych, biologicznych, $\mathrm{z}$ badaniami nad procesami poznawczymi włącznie. Na ile ta nowa perspektywa wnosi nowe możliwości, jest sprawą dyskusji i czasu.

Danuta Minta-Tworzowska

Instytut Archeologii, Wydział Historyczny, Uniwersytet im. Adama Mickiewicza ul. Umultowska 89D, 61-614 Poznań, Poland danminta@amu.edu.pl 